\title{
Leucophanes: A genus newly added to the moss Flora of West Bengal
}

\author{
Pamela Saha ${ }^{1}$, Animesh Maji ${ }^{2}$ and K. Karthigeyan ${ }^{2 *}$ \\ 'Bijoy Krishna Girls' College, Department of Botany, \\ Howrah Railway Station, Howrah - 711101, West Bengal, India \\ ${ }^{2}$ Central National Herbarium, Botanical Survey of India, A.J.C.B. Indian Botanic Garden, Botanic \\ Garden P.O., Howrah - 711103, West Bengal, India. \\ *Corresponding author: karthigeyan.murthy@gmail.com
}

\section{ल्यूकोफेनिस: पश्चिम बंगाल के मस फ्लोरा में हाल ही में संकलित एक वंश}

पामेला साहा, अनिमेष माजी एवं के. कार्तिगेयन

\section{सारांश}

ल्यूकोफोनिज ऑक्टोब्लीफरॉइडडिस ब्रिड. जो केलिमपेरेसी कुल से है, को पश्चिम बंगाल के सुंदरबन जैवमंडल प्रतिबंधित क्षेत्र से प्रथम बार अभिलेखित किया गया है। प्रस्तुत शोध पत्र में इस जाति का विस्तृत वर्णन अन्य संबंधित आंकड़ों के साथ दिये गये हैं।

\begin{abstract}
Leucophanes octoblepharioides Brid., belonging to the family Calymperaceae, is reported for the first time in West Bengal from the Sundarban Biosphere Reserve. Detailed description of the species along with other relevant data are provided here.
\end{abstract}

Keywords: Calymperaceae, Bryophyta, Leucophanes, Mangrove, Sundarban

\section{INTRODUCTION}

The genus Leucophanes was established by Bridel (1826). Plants of Leucophanes are characterized by whitish-green leaves growing in loose to dense tufts or cushions; stems erect, sparsely branched, branches short; leaves multi-stratose, narrowly to broadly lanceolate to retuse at apex, costa percurrent to short excurrent, with a stereid band (Promma \& Chantanaorrapint 2013).

During the recent floristic survey tour to different localities of Sundarban Biosphere Reserve as a part of the studies on "Assessment of Diversity and Distribution of Plants, Algae and Macro fungi in the Sundarban Biosphere Reserve, India" some moss specimens were collected. 'The Sundarbans was declared as Sundarban Reserve Forests in 1876 and as a Natural World Heritage Site by the UNESCO in 1997 to conserve all its unique flora and fauna' (Aziz \& Paul, 2015). The area has a unique diversity and ecosystem. Phyto-geographically the area is also very rich and unique due the presence mangrove forests. Though the Sundarban Biosphere Reserve is surveyed repeatedly for variety of studies, the bryoflora of this area was quite neglected. Gangulee (1969-1980) reported only two species under two genera and two families, viz. Chameleion peguense (Besch.) L.T. Ellis (Calymperaceae) and Brachymenium indicum (Dozy and Molk.) Bosch. and Sande Lac. (Bryaceae), from Sundarban region of West Bengal. 


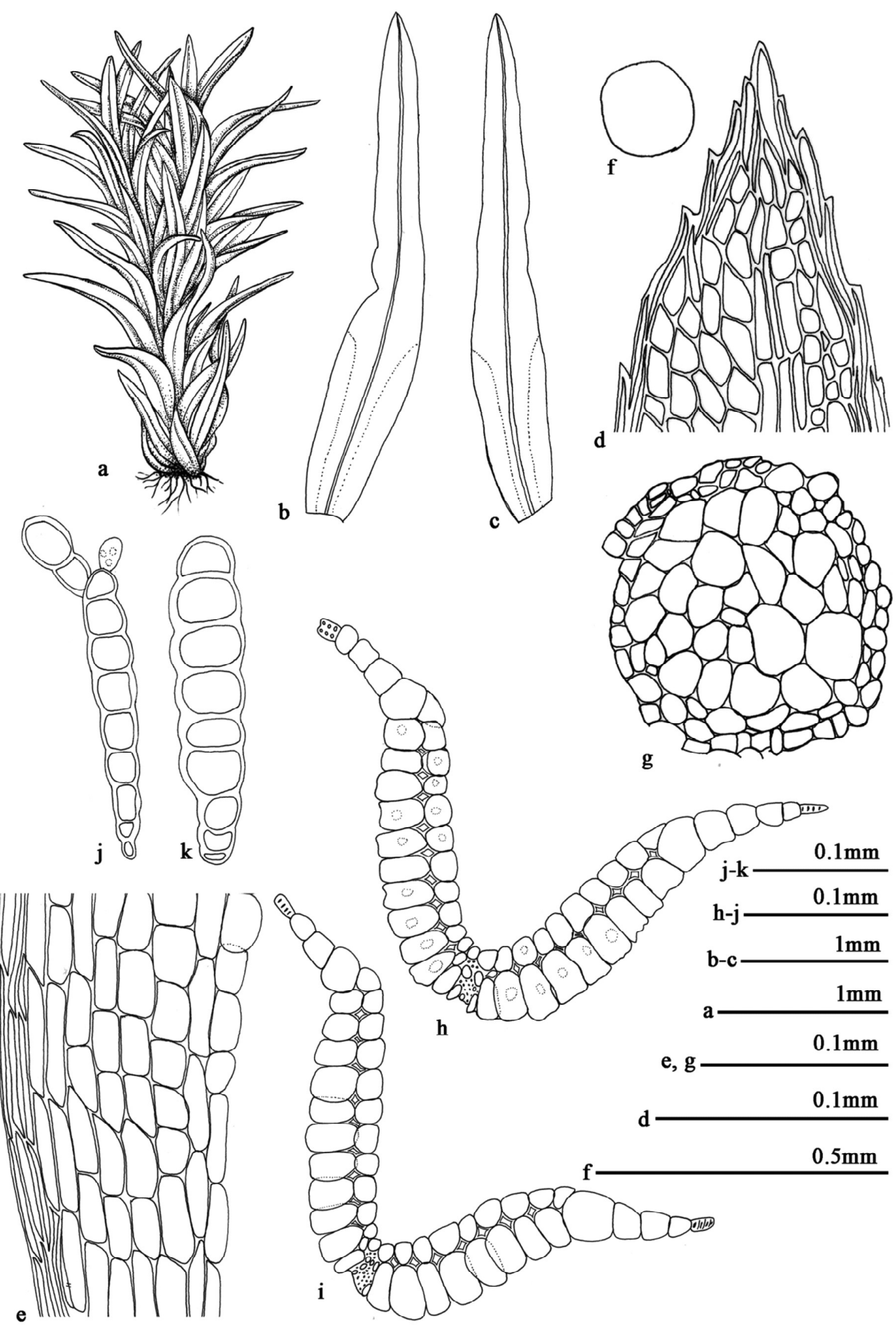

Fig. 1: Leucophanes octoblepharioides Brid.: a. wet plant, b-c. leaves, d. leaf apical cells, e. leaf laminal and marginal cells, f-g. transverse section of stem, h-i. transverse section of leaves, j-k. gemma (from K. Karthigeyan and A. Maji 170). 


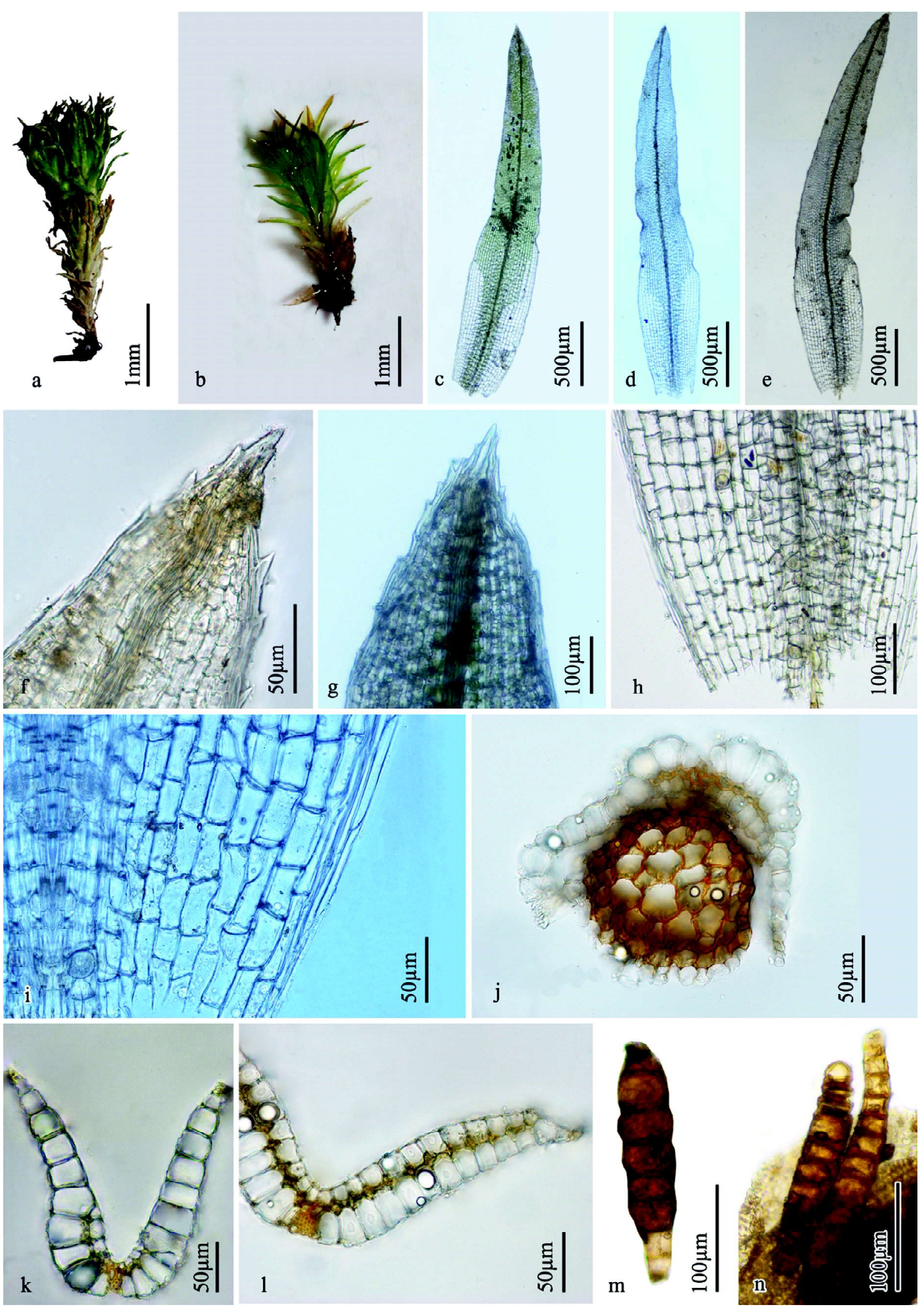

Fig. 2: Leucophanes octoblepharioides Brid.: a. dry plant, b. wet plant, c-e. leaves, f-g. leaf apical cells, h-i. leaf marginal and laminal cells, $\mathbf{j}$. transverse section of stem, $\mathbf{k}-\mathbf{l}$. transverse section of leaves, $\mathbf{m}-\mathbf{n}$. gemma (from K. Karthigeyan and A. Maji 170). 
A comprehensive literature study (Gangulee 1971; Eddy 1988; Promma \& Chantanaorrapint, 2013; Bang-juan \& He, 1999) and a thorough examination of the specimens revealed that the specimens belongs to Leucophanes octoblepharoides Brid., a member of the acrocarpous moss family Calymperaceae. The family Calymperaceae, represented by about 213 species under 10 genera (Crosby \& al., 1999) worldwide, is mostly confined to the tropical and subtropical regions particularly in Asia and Africa (Salazar Allen 1993). The genus Leucophanes is represented by 12 species (Salazar Allen 1993; Promma and Chantanaorrapint, 2013) to 15 species (Crosby \& al., 1999) worldwide. The genus was earlier known to be represented by four species in India (Gangulee 1971; Lal 2005; Dandotiya $\&$ al., 2011). Presently, the species Leucophanes glaucescens Müll. Hal. ex M. Fleisch. and L. albescens Müll. Hal., both are now treated as synonyms of Leucophanes glaucum (Schwaegr.) Mitt. and L. nicobaricum Müll. Hal. ex Gangulee is now treated as a synonym of L. octoblepharoides Brid. (Enroth 1990). According to the current estimates, the genus Leucophanes is represented by two species in India. The members of the Indian Leucophanes are chiefly distributed in Andaman and Nicobar Islands, Western Ghats and the Eastern Himalaya. Leucophanes octoblepharoides was earlier recorded from the Assam and Arunachal Pradesh. This species as well as the genus Leucophanes is a new addition to the bryoflora of West Bengal. A total of 350 species and 25 infraspecific taxa under 156 genera and 46 families of mosses are reported from West Bengal so far (Gangulee 1969-1980; Bhattacharya 2005; Saha 2019). Addition of this species has increased the number of species to 351 and genera to 157. Detailed description of the aforementioned species along with other relevant data is provided.

\section{MATERIALS AND METHODS}

Specimens were collected from Sundarban Biosphere Reserve, West Bengal. Properly preserved and dried specimens are deposited at Central National Herbarium (CAL). The morphological descriptions of the newly reported species are based on freshly collected specimens. Morpho-taxonomic investigations of the specimens were performed using Leica DFC550 Stereo zoom microscope and Olympus CX41 biological microscope. Drawings were prepared with drawing attachment of Olympus CX41 microscope. Photomicrographs were captured with the help of Nikon
Eclipse $\mathrm{N} i$-U compound microscope. A brief taxonomic description and line drawing along with photomicrographs are provided. Relevant literatures were consulted for confirmation of the identity of the species.

\section{TAXONOMIC TREATMENT}

Key to the species:

1a. Leaves often twisted when dry; leaf apices mostly acute to apiculate, margins finely serrulate and gradualy becoming more strongly serrate above the middle, leaf bases sheathing; costa strongly spinose on the dorsal side in the upper part of the leaves ...L. glaucum

1b. Leaves little altered when dry; leaf apices mostly obtuse to acute, margins serrulate above the middle, serrate near apex, leaf bases not sheathing; costa smooth on the dorsal side, rarely spinose at apex

\section{...L. octoblepharoides}

Leucophanes octoblepharioides Brid., Bryol. Univ. 1: 763. 1827; Eddy, Handbook of Malesian Mosses 2: 46. 1990; Promma \& Chantanaorrapint, Thai. Forest Bull., Bot. 41: 31. 2013.

(Fig. $1 \& 2$ )

[Type: Indonesia: Java, Nees v. Esenbeck s.n.]

Plants medium-sized, glossy, whitish to greyish green, forming dense or loose tufts; stems erect, $1-1.5 \mathrm{~cm}$ high, simple or branched; transverse section without central strand; leaves crowded, easily falling off, erectspreading when moist, little altered when dry; linearlanceolate, $3-4 \mathrm{~mm} \times 0.7-0.8 \mathrm{~mm}$, flat above, slightly concave at the base, obtuse to acute at the apex; margins distinctly bordered, with 2-4 rows of very long, narrow, cartilaginous, hyaline and thick-walled cells throughout, entire below, serrulate above the middle, serrate near the apex; hyaline lamina restricted to the lowermost part of the leaf, $1 /{ }_{3}-1 / 4$ of leaf length, laminal cells quadrate to short rectangular, hyaline; costa smooth on the dorsal surface in the upper parts of leaves, costa shows one layer of quadrangular chlorocysts between two layer of much larger leucocysts and a median dorsal prominent stereid band.

Gemma present at the leaf apex, spindle shaped, 100$150 \mathrm{~mm}$ in length. Sporophyte not seen.

Habitat: Epiphytic on Phoenix sylvestris (L.) Roxb.

Specimen Examined: INDIA, West Bengal, South 24Parganas, Sundarban, $22^{\circ} 05^{\prime} 49.6^{\prime \prime} \mathrm{N}, 88^{\circ} 45^{\prime} 56.9^{\prime \prime} \mathrm{E}$, 27.02.2020, K. Karthigeyan \& A. Maji 170 (CAL).

Distribution: India: Arunachal Pradesh, Assam, Kerala, 
Tamil Nadu, West Bengal (Sundarban); Australia, Bangladesh, China, Indonesia, Japan, Malaysia, Myanmar, Nepal, New Guinea, Philippines, Sri Lanka, Sumatra, Tahiti, Thailand, Vietnam.

Notes: The species of Leucophanes are quite little known mosses in India. Leucophanes octoblepharoides can easily be recognised by their leaves which are whitishgreen, caducous, linear-lanceolate, apex serrate and costa smooth on the dorsal surface along the upper parts of leaves. The species was earlier reported from Assam and Arunachal Pradesh in the North Eastern India. The present collection is the first report of the occurrence of this genus and species in West Bengal from the Sundarban Biosphere Reserve.

\section{ACKNOWLEGDEMENTS}

The authors are grateful to the Director, Botanical Survey of India, Kolkata and Head of Office, Central National Herbarium for the facilities. Thanks are due to the Director, Joint Director and the Divisional Forest Officer, Sundarban Biosphere Reserve, and Authorities of Sundarban Tiger Reserve, West Bengal for their help and support during the field Survey. Thanks are also due to Ministry of Environment, Forest and Climate Change, Govt of India and West Bengal Forest Department for the financial support.

\section{REFERENCES}

AZIZ, A. AND R.A. PAUL 2015. Bangladesh Sundarbans: Present Status of the Environment and Biota. Diversity 7:242-269.

BANG-JUAN, L. AND S. HE 1999. Leucobryaceae. In: Chien, G., Crosby, M.R. (Eds.), Moss Flora of China, Volume 1. Science Press (Beijing) and Missouri Botanical Garden Press (St. Louis). pp. 242-258.

BHATTACHARYA, P.K. 2005. Bryophyte flora of Barddhaman district, West Bengal. Bull. Bot. Surv. India 47 (1-4): 11-42.
BRIDEL S.E. 1826. Bryologia Universa ad Novam Methodum Dispositio, Historia et Descriptio omnium Muscorum Frondosorum Hucusque cognitorum cum Synonymia ex Auctoribus Probatissimis. Vol. 1. Suppl. Sumtibus Joan. Ambros. Barth., Lipsiae. Germany.

CROSBY, M.R., R.E. MAGILL, B. ALLEN AND S. HE 1999. A Check list of The Mosses. St. Louis: Missouri Botanical Garden.

DANDOTIYA, D., H. GOVINDAPYARI, S. SUMAN AND P.L. UNIYAL 2011. Checklist of the bryophytes of India - Archive for Bryology 88: 1-126.

EDDY, A. 1990: A Handbook of Malesian Mosses Volume 2 (Leucobryaceae to Baxbaumiaceae). British Museum (Natural History).

ENROTH, J. 1990. Bryophyte flora of the Huon Penninsula, Papua New Guinea. XXXVI. Leucobryaceae (Musci). Acta Bot. Fenn. 139: 65-120.

GANGULEE, H.C. 1971: Mosses of Eastern India and Adjacent Regions, A Monograph. Fascicle 2, Calcutta.

GANGULEE, H.C. 1969-1980: Mosses of Eastern India and Adjacent Regions, A Monograph. Fascicle 1-8, Calcutta.

LAL, J. 2005: A Checklist of Indian Mosses. Bishen Singh Mahendra Pal Singh, Dehra Dun, India.

PROMMA, C. AND S. CHANTANAORRAPINT 2013. The genus Leucophanes (Calymperaceae, Bryophyta) in Thailand. Thai. Forest Bull., Bot. 41:23-38.

SAHA, P. 2019. Taxonomic studies on mosses of Darjeeling district with emphasis on their anatomical details. Ph.D. Thesis (unpublished), University of Calcutta, West Bengal, India. pp. 1-1110.

SALAZAR ALLEN N. 1993. A revision of the pantropical moss genus Leucophanes Brid. Bryophytorum. Bibliotheca 46: 1-281. 